\title{
Latest Jurassic to earlier Early Cretaceous foraminifers from the Torinosu-type limestone blocks in Southwest Japan: Constraints on chrolonogic calibration of the Torinosu-type limestones
}

\author{
Fumio Kobayashi ${ }^{*}$ and Roland Wernli** \\ Received April 28, 2012 \\ Accepted September 6, 2012 \\ Institute of Natural and Environmental Sci- \\ ences, University of Hyogo, Sanda, Hyogo \\ 669-1546, Japan \\ ** Département de Géologie et Paleontology, \\ Université de Genève, 13, rue des Maraîch- \\ ers, 1211, Genève, Suisse \\ Corresponding author; F. Kobayashi, \\ kobayasi@hitohaku.jp
}

\begin{abstract}
Thirty-six taxa of foraminifers were recognized from 31 samples of the Torinosu-type limestone blocks in South of Yatsushiro, Azamui (Kyushu), Nomura (Shikoku), and Yura (Kii) areas, Southwest Japan. Those identified in species level are confined to five: Nautiloculina broennimanni, Freixialina planispiralis, Charentia cuvillieri, Melathrokerion spirialis, and Pseudocyclammina lituus. Such genera as Kurnubia and Alveosepta showing the pre-Kimmeridgian, and orbitolinids characteristic in the post-late Hauterivian are completely absent in them. The Torinosu-type limestones studied are assigned to the latest Jurassic to earlier Early Cretaceous based on the biostratigraphic distribution of the identified five species in the western Tethyan region and chronologic constraints on the studied material excluding the pre-Kimmeridgian and post-late Hauterivian faunal elements.
\end{abstract}

Key words: Foraminifers, Torinosu-type limestone, Latest Jurassic, earlier Early Cretaceous, Southwest Japan, chronologic calibration

\section{Introduction}

Jurassic/Cretaceous Torinosu limestone and lithologically similar Torinosu-type limestones are distributed in the Middle Chichibu (Kurosegawa) and Southern Chichibu terranes and partly in the Northern Shimanto Terrane of Southwest Japan in zonal alignments. Their eastward extension reaches to the Northeast Japan from the Kanto Mountains (Huzimoto, 1939; Sashida et al., 1992) to the Iwaizumi area of the northern Kitakami Mountains (Onuki, 1981) through the Soma area of the eastern part of the Abukuma Mountains (Mori, 1963). These limestones are characteristic in their bituminous composition and having detrital quartz grains. Many megafossils such as stromatoporoids, hexacorals, hydrozoans, and sclerosponges are contained in them.

The age of the Torinosu and Torinosu-type limestones have been determined wholly as Middle to Late Jurassic by stromatoporoids (Yabe and Sugiyama, 1935), hexacorals (e.g., Eguchi, 1951; Mori, 1963; Yamagiwa et al., 2011), and almost all fossils reported by 1960 (Tamura, $1961 \mathrm{a}, \mathrm{b})$. The surrounding sandstone and mudstone were determined as Middle Jurassic (Bajocian) to the earliest Cretaceous by ammonoids, bivalves, and brachiopods (e.g., Kimura, 1956; Tamura, 1960, 1961a). Radiolarian biostratigraphy since 1980's has revealed the age of siliciclastic rocks around limestones ranging up to the Berriasian and further to the Barremian (e.g., Yao, 1984; Aita and Okada, 1986; Morino, 1993; Kashiwagi and Yao, 1999; Kozai et al., 2004).

The strontium isotopic age of the Torinosu-type limestones corresponds to the middle Tithonian (Shiraishi et al., 2005) and late Kimmeridgian to early Berriasian (Kakizaki et al., 2012). That of the Torinosu limestone at the type locality is from latest Kimmeridgian to latest Berriasian (Kakizaki et al., 2012). These estimated depositional periods are well concordant with those based on calcareous nannofossils from latest Jurassic to early Berriasian (Aita and Okada, 1986) and benthic foraminifers from Tithonian to Berriasian (Kobayashi and Vuks, 2006). They are discordant with early Aptian age based on planktonic foraminifers from the Sanchu area (Sashida et al., 1992; Inose and Sashida, 2011) and Middle Jurassic age based on radiolarians from Southern Chichibu Terrane (Sashida et al., 1989; N. Ishida, 2006).

Two foraminiferal genera, Pseudocyclammina Yabe and Hanzawa, 1926 and Torinosuella Maync, 1959 were established based on the material from the Torinosu limestone of the Sakawa area. The type species of these two genera, Pseudocyclammina lituus (Yokoyama, 1890) and Torinosuella peneropliformis (Yabe and Hanzawa, 1926) have been studied taxonomically and biostratigraphically in the western Tethyan regions (e.g., Septfontaine, 1980; Cherchi and Schroeder, 2005). 


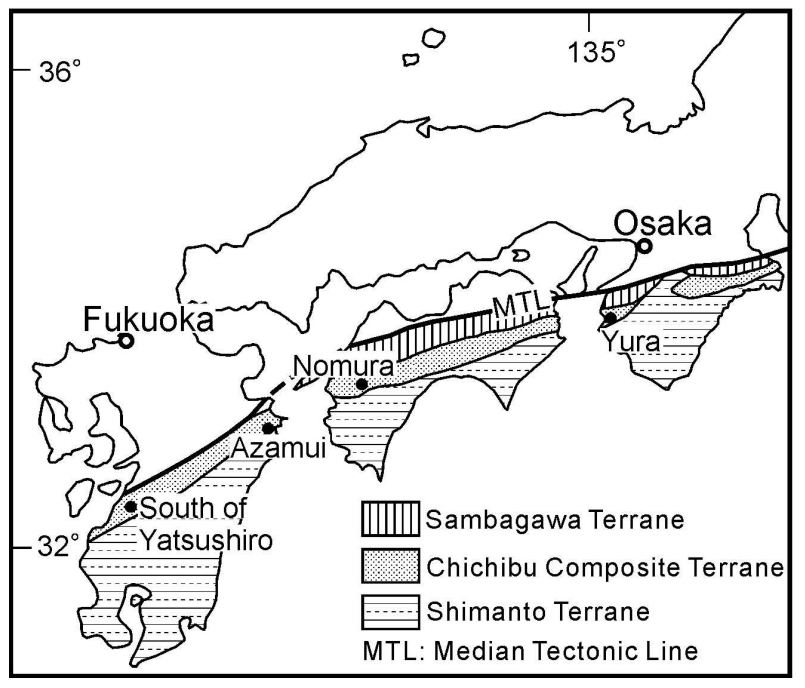

Fig. 1. Sample localities of the Torinosu-type limestone blocks in Southwest Japan. Southwest Japan is tectonically divided into the Sambagawa, Chichibu Composite, and Shimanto terranes.

While, Jurassic/Cretaceous foraminiferal works are very few in Japan as well as East and Southeast Asia. One of the author, F. Kobayashi have been attempted to make clear the faunal composition of foraminifers and the age of the Torinosu and Torinosu-type limestones based on comparative studies with those accumulated in the western Tethyan regions under the cooperation of workers in and outside Japan.

This paper summarizes the foraminiferal faunas of the Torinosu-type limestone blocks in South of Yatsushiro, Azamui, Nomura, and Yura areas, Southwest Japan in addition to the brief geological accounts on sample localities (Fig. 1). Foraminifers of these four areas are compared faunistically and biostratigraphically with those of the Torinosu-type limestones of the Southern Kanto Mountains (Kobayashi and Vuks, 2006), the Torinosu limestone of the Sakawa area (unpublished data by authors), and coeval ones of the western Tethyan regions. Geologic age of the Torinosu-type limestones inferred on the basis of other microfossils is summarized and commented on. Materials treated herein are new to a chronologic calibration of the Torinosu-type limestone and available for further studies of the limestone in these four and many other areas in Japan. All limestone thin sections used in this paper are stored in the Museum of Nature and Human Activities, Sanda, Hyogo, Japan (Fumio Kobayashi Collection, MNHAH).

\section{Geologic summary and Samples}

\section{South of Yatsushiro}

The Torinosu-type limestone blocks in the western part of Kyushu are distributed in the middle course of the Kuma River, south of Yatsushiro, Kumamoto Prefecture. Those exposed at Hashirimizu and Sakamoto are assignable into the Middle Chichibu (Kurosegawa) Terrane and those at Shiraki in the Southern Chichibu Terrane (Fig. 2A). Pre-Silurian rocks and serpentinite are conspicuous in the Middle Chichibu Terrane. The southern part of the Southern Chichibu Terrane is occupied by the Konose Group represented by huge seamount limestone blocks with Late Triassic foraminifers and Megalodont bivalves (Kanmera and Furukawa, 1964; Tamura, 1983; Chablais et al., 2011).

(1) Hashirimizu (Sample Ha-1-Ha-3) Seventy meters thick siliciclastic strata with a few small limestone blocks are distributed in the upper course of Hashirimizu-dani, a tributary of the Kuma River about $6 \mathrm{~km}$ ENE of Sakamoto (Fig. 2B). They were referable to a part of the Matsukuma Formation and thought to the Upper Triassic (Carnian) based on bivalves from sandy mudstone (Matsumoto and Kanmera, 1964). Three erratic limestone samples are examined. Foraminifers are contained commonly or rarely in them.

These limestones are thought to have been originally embedded within muddy rocks. They are gray to dark gray, ooid grainstone with many fossil fragments (Ha-1) and floatstone with abundant megafossils common in the Torinosu limestone such as sclerosponges, hydrozoans, and thick-shelled bivalves. These lines of lithologic and faunal evidence indicate that the siliciclastic rocks with Torinosu-type limestones in the Hashirimizu area should be separated from the Matsukuma Formation and reassigned to a part of the Sakamoto Formation or treated as an independent lithostratigraphic unit.

(2) Sakamoto (Sample Sk-1-Sk-5) Mudstone and sandstone commonly intercalating oolitic limestone as thick as 2 to 4 meters are exposed near the Sakamoto Station (Fig. 2B). They are assigned to the Upper Member of the Sakamoto Formation (Tamura, 1960) or to the Lower Member of the formation (Matsumoto and Kanmera, 1964; Nishizono, 2001). Late Jurassic (Oxfordian to Tithonian) bivalves are reported from black mudstone of the Upper Member (Tamura, 1959a, b; 1960). Nearly coeval radiolarians are reported from the Lower Member (Nishizono, 2001). Age-diagnostic microfossils have not been described from the limestone. Foraminifers are rarely contained in dark gray ooid grainstone in four samples (Sk-1-Sk-3, Sk-5) but not contained in Sk-4. Sk-1-Sk-3 were collected from three levels of the largest limestone block in the area, and Sk-5 from $1.5 \mathrm{~m}$ thick limestone block $350 \mathrm{~m}$ NE of the largest block.

(3) Shiraki (Sample Sh-1) Jurassic to Cretaceous ac- 



Fig. 2. A: Tectonic division of south of Yatsushiro, western part of Kyushu showing localities of Sakamoto, Hashirimizu, and Shiraki. B: Distribution of sample localities Sakamoto (Sk-1 to Sk-5) and Hashirimizu (Ha-1 to Ha-3) and the Sakamoto and Matsukuma formations (Matsumoto and Kanmera, 1964). C: Map showing sample locality Shiraki (Sh-1), Southwest of Konose along the middle course of Kuma-River.

cretionary complexes along the Kuma River are divided into five units (Nishizono et al., 1997). Among them, the Ebirase Unit contains Torinosu-type limestone blocks within mudstone dated as Tithonian (Nishizono et al., 1997) or Kimmeridgian to Tithonian (N. Ishida, 2006) by radiolarians. Torinosu-type limestone was dated as old as Middle Jurassic (Bathonian) by N. Ishida (2006).

Although tectonostratigraphic works near the Torinosu-type limestone exposed at Shiraki are few, the limestone block and the surrounding siliciclastic rocks at Shiraki probably correspond to a part of those of the
Ebirase Unit (Fig. 2C). Foraminifers are contained in dark gray ooid bioclastic grainstone/packstone (Sh-1) with many megafossil fragments.

\section{Azamui (Sample Az-1-Az-17)}

The Azamui area, eastern part of Kyushu is located in the boundary between the Southern Chichibu Terrane in the north and the Shimanto Terrane in the south. The Nakano Belt, southernmost tectonic unit of the Southern Chichibu Terrane consists of the Tsui and Yukagi formations (Kambe and Teraoka, 1968). These formations are correlated by Kambe and Teraoka (1968) to the Konose Group of western Kyushu. Jurassic to Cretaceous age of 


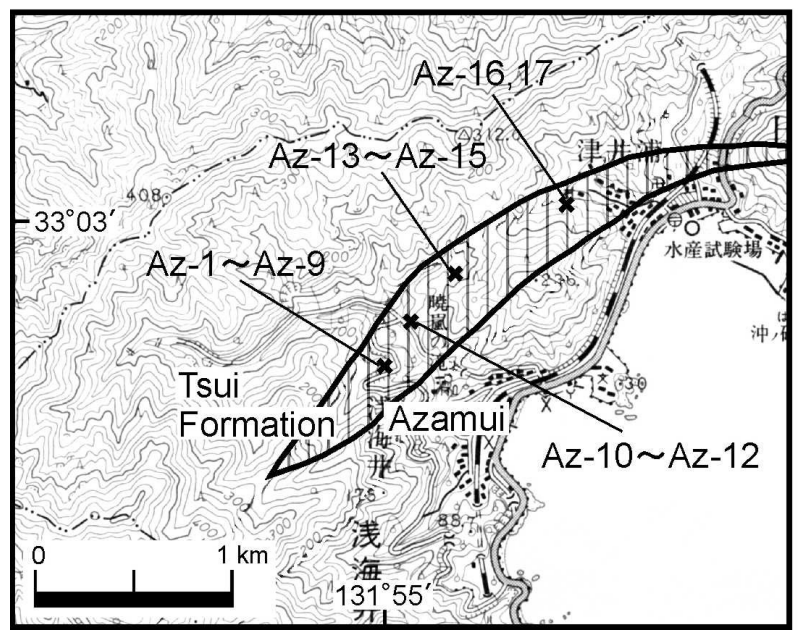

Fig. 3. Distribution of sample localities Azamui (Az-1 to Az-17) and the Tsui Formation (Nishi, 1994).

the Tsui Formation was determined by the occurrence of megafossils characteristic in the Torinosu limestone and that of the Yukagi Formation by ammonoids (Kambe and Teraoka, 1968). Yoshida (1985) assigned both formations into the Northern Shimanto Terrane based on early to middle Cretaceous radiolarians. On the other hand, Nishi (1994) considered that the Tsui Formation is Upper Jurassic and the Yukagi Upper Jurassic to Lower Cretaceous and both formations belong to the Southern Chichibu Terrane.

Seventeen samples were collected from a few to ten meters length, gray to black limestones of the Tsui Formation (Fig. 3). All of the limestone are an independent block or a fragment surrounded by muddy rocks exposed along the logging road and small valley. They consist of rudstone (Az-1, Az-3, Az-4, Az-11, Az-13, Az-15), boundstone (Az-2, Az-5, Az-7), ooid grainstone (Az-10, Az-14, Az-16), grainstone/packstone (Az-6, Az8, Az-9), and grainstone/rudstone (Az-12, Az-17). Stromatoporoids, hexacorals, and sclerosponges are especially abundant in Az-2, Az-4, and Az-15. Foraminifers are recognized in eight samples (Az-1, Az-3, Az-6, Az8, Az-10, Az-11, Az-14, Az-17).

\section{Nomura (Sample Nm-1-Nm-3, Nm-50)}

Although detailed tectonostratigraphy of the Southern Chichibu Terrane in the Nomura area, western Shikoku remains uncertain, strata with Torinosu-type limestones in the Shirokawa area, east of Nomura are collectively assigned to the Upper Jurassic Imaidani Group originally defined by Nakagawa et al. (1959) and later correlated to the Torinosu Group in the Sakawa area (Takei and Matsuoka, 2004). Strata with Torinosu-type limestones exposed at some localities westwards from the Shiroka-

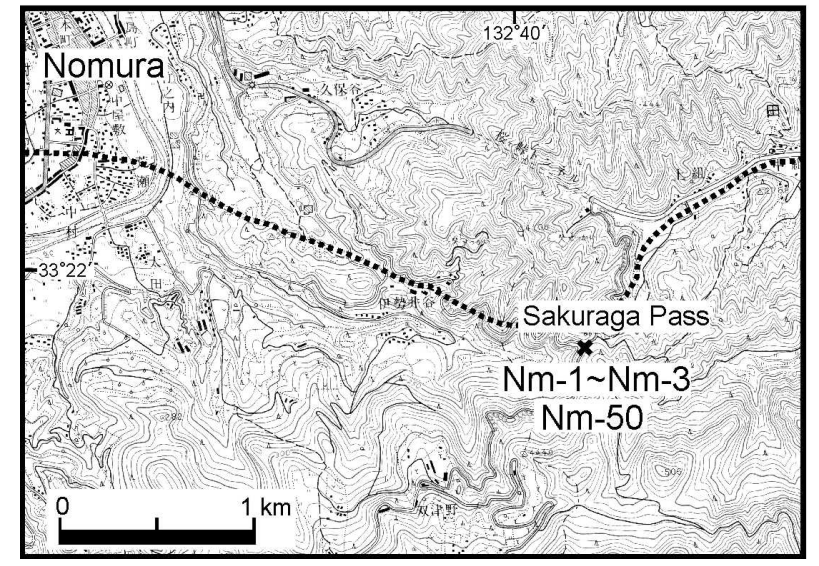

Fig. 4. Sample localities (Nm-1 to Nm-3, Nm-50) at Sakuraga Pass in the Nomura area. Northern and southern areas bounded by dotted line are possibly assigned into the Nomura Group and to the western extension of the Imaidani Group, respectively (Nakagawa et al., 1959; Takei and Matsuoka, 2004).

wa area are assumed to correspond to a part of the Imaidani Group in the Shirokawa area. Argillaceous rocks of the group in the Shirokawa area are thought as old as Tithonian (Yao et al., 1982, p. 31, 36).

Four samples were collected from separate, small limestone blocks and fragments densely packed within muddy rocks partly showing conglomeratic appearance at Sakuraga Pass in the Nomura area (Fig. 4). They consist of bioclastic packstone and rudstone, and contain foraminifers in addition to many fragments of stromatoporoids and sclerosponges. Pseudocyclammina characteristic in the Torinosu limestone is abundantly contained in a small pebble of conglomeratic limestone of Sample Nm-1.

\section{Yura}

Torinosu-type limestones of the Southern Chichibu Terrane in the western part of Kii Peninsula are distributed in zonal alignment in the Yura area. They are assigned into the Yura and Kamiya formations (Fig. 5; Yao, 1984). Based on radiolarians from the mudstone, the Yura Formation is thought to be the Tithonian to Berriasian, and the Kamiya Formation the Valanginian to Barremian, (Yao, 1984).

(1) Kamiya (Sample Ka-1-Ka-4) Four samples collected from the separate limestone blocks exposed at Kamiya are assigned to the Kamiya Formation. They are dark gray, thickly bedded and lithologically similar each other, and consist of bioclastic packstone partly with pelloids and ooids. Foraminifers are rarely contained in all these samples.

(2) Mizukoshi (Sample Mi-1-Mi-10) Limestone blocks are well developed in the Yura Formation in the 


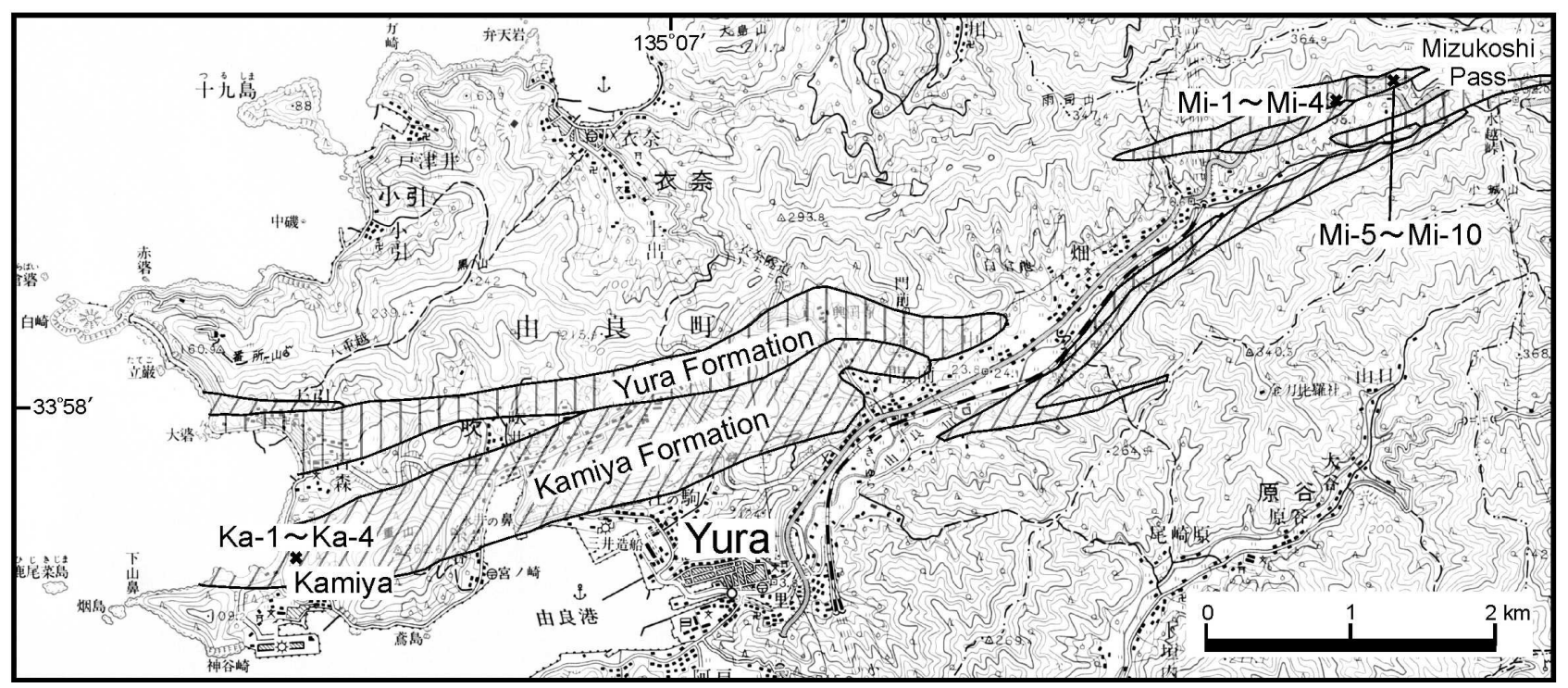

Fig. 5. Distribution of sample localities in the Yura and Kamiya formations in the Yura area (Yao, 1984).

west of Mizukoshi Pass. They are several to $50 \mathrm{~m}$ or more in length and lithologically highly variable such as stromatoporoid framestone, sclerosponge boundstone, grainstone/packstone, ooid grainstone, and pelloid wackestone. Foraminifers are poor or absent in framestone and boundstone (Mi-8-Mi-10), and rarely recognized in seven samples (Mi-1-Mi-7) of gray to dark gray, ooid bioclastic grainstone and ooid grainstone collected from separate blocks of a few to $50 \mathrm{~m}$ in length. They are the commonest in Sample Mi-5 (ooid bioclastic grainstone).

\section{Fauna and age}

Thirty-six taxa of foraminifers are distinguished in the Torinosu-type limestone studied in the four areas (Table 1, Figs. 6-11). However, those identified in species level are confined to five among 27 species assigned to 17 genera. There are many taxa whose generic assignment is impossible or exactly indeterminate. Samples containing five or more taxa are restricted to 10 (Ha-1, Sk-1, Sk-2, Sh-1, Az-6, Nm-1, Nm-50, Ka-2, Mi-1, Mi-5). Ha- 1 is the most variable in foraminifers and 14 taxa are amounted. These values suggesting the abundance and variability of foraminifers are generally thought to be lower than those of the Southern Kanto Mountains and the Sakawa area. For example, 23 and 22 taxa are identified respectively in Sample G-205 of the Kanto (Kobayashi and Vuks, 2006) and in Sample Sa-27 of Sakawa (unpublished data by authors)

So far as the 31 samples with foraminifers (Table 1) and 13 samples without them are concerned, the occurrence and frequency of foraminifers are strongly con- trolled by limestone facies. Foraminifers are relatively common in fine-grained bioclastic limestone and oolitic limestone, and generally poor or barren in boundstone with various kinds of metazoans, especially in those referable to biolithite typical for reef cores represented by Sample Az-7 in the Azamui area and Sample Mi-9 in the Yura area. Marked facies control of foraminifers dependent on limestone lithologies is also recognized in the Torinosu-type limestone of the Southern Kanto Mountains and in the Torinosu limestone of the Sakawa area.

There are five species available for age assignment of the Torinosu-type limestone: Nautiloculina broennimanni Arnaud-Vanneau and Peybernes, 1978; Freixialina planispiralis Ramalho, 1969; Charentia cuvillieri Neumann, 1965; Melathrokerion spirialis Gorbachik, 1968; and Pseudocyclammina lituus (Yokoyama, 1890). They are recognized in 11 samples and not in other 20 samples (Table 1).

Nautiloculina broennimanni was originally described from the lower Aptian (Bedoulian) of the Vercors (SE France) and the upper Hauterivian to the lower Aptian of Pyrénées (Arnaud-Vanneau and Peybernes, 1978), and later from the upper Berriasian to Valanginian of Salève (France) (Salvini-Bonnard et al., 1984), and the Berriasian of northwest Anatolia (Altiner, 1991). This species ranges from the Late Tithonian to Aptian according to Bucur et al. (1995), and the Tithonian to Barremian according to Bucur et al. (2004). Freixialina planispiralis is the type species of the genus and a marker species of the Kimmeridgian to Tithonian of Portugal (Ramalho, 1969) and Carpathians (Dulub, 
Table 1. Foraminifers of the Torinosu-type limestones.

\begin{tabular}{|c|c|c|c|c|c|c|c|c|c|c|c|c|c|c|c|c|c|c|c|c|c|c|c|c|c|c|c|c|c|c|c|}
\hline \multirow[b]{3}{*}{ Species } & \multirow{2}{*}{\multicolumn{3}{|c|}{ 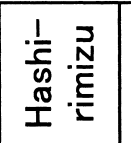 }} & \multirow{2}{*}{\multicolumn{4}{|c|}{ 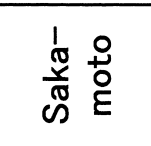 }} & \multirow{3}{*}{\begin{tabular}{|l|}
$\bar{x}$ \\
$\bar{v}$ \\
$\frac{\bar{v}}{c}$ \\
1 \\
\end{tabular}} & \multirow{2}{*}{\multicolumn{8}{|c|}{ Azamui }} & \multirow{2}{*}{\multicolumn{4}{|c|}{ Nomura }} & \multicolumn{11}{|c|}{ Yura } \\
\hline & & & & & & & & & & & & & & & & & & & & & \multicolumn{4}{|c|}{ Kamiya } & \multicolumn{7}{|c|}{ Mizukoshi } \\
\hline & 1 & 2 & 3 & 1 & 2 & 3 & 5 & & 1 & 3 & 6 & 8 & 10 & 11 & 14 & 17 & 1 & 2 & 3 & 50 & 1 & 2 & 3 & 4 & 1 & 23 & 3 & 4 & 5 & 6 & 7 \\
\hline Nautiloculina broennimanni & & & & & & & & & & & & & & & & & & & & & & & & & $x$ & & & & $x$ & & \\
\hline Freixialina planispiralis & & & & & & & & & & & & & & & & & & & & & & $x$ & & & & & & & & & \\
\hline Ammobaculites sp. & $x$ & & & & & & & & & & & & & & & & & & & & $x$ & & & & & & & & & & \\
\hline Ammobaculites? sp. & & & & & & & & & & & & & & & & & & & & & & & & & & & & & & & $x$ \\
\hline Lituolinidae indet. & & & & & & & & & & & & & & & & & & & $x$ & & & & & & & & & & & & \\
\hline Lituolinidae? indet. & & & & & & & & & & & & & & & & & & & & $x$ & & & & & & & & & & & \\
\hline Acruliammina sp. & & & & & & & & & & & $x$ & & & & & & & & & & & & & & & & & & & & \\
\hline Acruliammina? sp. & $x$ & & & & & & & & & & & & & & & & & & & & & & & & & & & & & & \\
\hline Haplophragmium cf. lutzei & $x$ & & & & & & & & & & & & & & $x$ & & & & & & & & & & & & & & & & \\
\hline Haplophragmium sp. & & & & & & & & & & & $x$ & $x$ & & & & & & & & & & . & & & & & & & & & \\
\hline Haplophragmium? sp. & & & & $x$ & $x$ & & & & & $x$ & & & & & & $x$ & $x$ & & & & & $x$ & & & & & & $x$ & $x$ & & \\
\hline Charentia cuvillieri & & & & & $x$ & & & $x$ & $x$ & & $\bar{x}$ & $x$ & $x$ & & & & & & & & & & & & & & & & & & \\
\hline Charentiidae indet. & & & & & & & & & & & & & & & & $x$ & & & & & & & & & & & $x$ & & & & \\
\hline Melathrokerion spirialis & $x$ & & & & $x$ & & & & & & & & & & & & & & & & & & & & & & & & & & \\
\hline Melathrokerion sp. & & $x$ & & $x$ & & $x$ & & & & & & & & & & & $x$ & & & $x$ & & & & & $x$ & & & & & & \\
\hline Pseudocyclammina lituus & & & & & & & & & & & & & & & & & $x$ & & & & & & & & & & & & & & \\
\hline Pseudocyclammina? sp. & $x$ & & & & & & & & & & & & & & & & & & & & & & & & & & & & & & \\
\hline Cyclamminidae? indet. & $x$ & & & & & & & & & & & & & & & & & & & & & & & & & & & & & & \\
\hline Broeckinella? sp. & & & & & & & & & & & & & & & & & & $x$ & & & & & & & & & & & & & \\
\hline Belorussiella cf. textilarioides & & & & & & & & & & & & & & & & & & & & & & & & & $x$ & & & & & & \\
\hline Belorussiella? sp. & & $x$ & & $x$ & & & $x$ & & & & $x$ & & & & & & & & & & & $x$ & & & & & & & & & \\
\hline Verneuilinidae indet. & & & & & & & & & & & & & & & & & $x$ & & & & $x$ & & & & & & & & & & \\
\hline Arenobulimina sp. & $x$ & & & & & & & $x$ & & & & & & & & & & & & $x$ & & & & & & & & & & & \\
\hline Textularia sp. & $x$ & & & & & & & $x$ & $x$ & & $x$ & & & & & $x$ & & & & & & $x$ & & & & $x$ & & & $x$ & & \\
\hline Textularia? sp. & $x$ & & & & & $x$ & & \begin{tabular}{c|c}
$x$ \\
\end{tabular} & & & $x$ & & & & & & & & & & & $x$ & & & & . & & & $x$ & & $x$ \\
\hline Textulariidae indet. & $x$ & $x$ & $x$ & & $x$ & 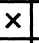 & $x$ & & & $x$ & $x$ & $x$ & & $x$ & & & $x$ & & & $x$ & & & & $x$ & \begin{tabular}{l|l}
$x$ & 3 \\
\end{tabular} & \begin{tabular}{l|l}
$\times$ & \\
\end{tabular} & $x$ & $x$ & $x$ & $x$ & \\
\hline Valvulinidae indet. & & & $x$ & $x$ & & & & $x$ & & & & & & & & & $x$ & $x$ & & & & & & & & & & & $x$ & & $x$ \\
\hline Quinqueloculina sp. & $x$ & & & $x$ & & & & & & & & & & & & & & & & & & & & & & & & & & & \\
\hline Quinqueloculina? sp. & & & & & & & & & & & & & & & & & & & $x$ & & & & & & & & & & & & \\
\hline Dentalina? sp. & & & & & & & & & & & & & & & & & & & & & & & $x$ & & & & & & & & \\
\hline Miliolidae indet. & $x$ & & & & & & & $x$ & & & & & & & & & $x$ & $x$ & & & & & & & $x$ & $x$ & & & & & \\
\hline Astacolus? sp. A & & & & & & & & & & & & & & & $x$ & & & & & & & & & & & & & & & & \\
\hline Astacolus? sp. B & & & & & & & & & & & & & & & & & & & & & $x$ & & & & & & & & & & \\
\hline Lenticulina sp. & $x$ & & & & & & & & & & & & & & & $x$ & & & $x$ & $x$ & $x$ & $x$ & $x$ & & & $x$ & & $x$ & $x$ & & \\
\hline Chalilovella sp. & $x$ & & & & & & & $x$ & & & & & & & & & & & & & & & & & & & & & & & \\
\hline Epistominidae indet. & & & & & $x$ & & & & & & & & & & & & & & & & & & & & & & & & & & \\
\hline
\end{tabular}

1972), and the Berriasian of Crimea (Dulub and Zhabina, 1993). According to Bucur et al. (2004), this species ranges from the Tithonian to Barremian.

Bucur et al. (2004) considered that Melathrokerion spirialis and Charentia evoluta (Gorbachik, 1968) are junior synonyms with Charentia cuvillieri. Both species are reported in the Southern Kanto Mountains (Kobayashi and Vuks, 2006). We agree with a junior synonymy of the latter but hesitate about that of the former. Charentia cuvillieri and related species are described from the Berriasian to lower Valanginian of northwest Anatolia (Altiner, 1991), the Barremian of Romania (Bucur et al., 1993), and Valanginian of eastern Serbia (Bucur et al., 1995). Moreover, this species ranges from the late Tithonian to Cenomanian in the western Tethyan regions according to Bucur et al. (2004). Melathrokerion spirialis is known originally from the lower Berriasian of Crimea (Gorbachik, 1968), and later from the Tithonian to Berriasian of Crimea, Caucasus, Syria and Algeria, and from the Berriasian of Switzerland (Kuznetzova and Gorbachik, 1985; Dulub and Zhanina, 1993).

Pseudocyclammina lituus is associated with Broeckinella magna Septfontaine, 1978 in the Torinosu limestone in Sakawa (unpublished data by authors). B. mag$n a$ is originally described from the Valanginian to Barremian of Savoie, France (Septfontaine, 1978) and is abundant and very characteristic in the Thurmanniceras otopeta ammonite zone (latest Berriasian to earliest Valanginian) in the Chambotte Formation of the Southern 

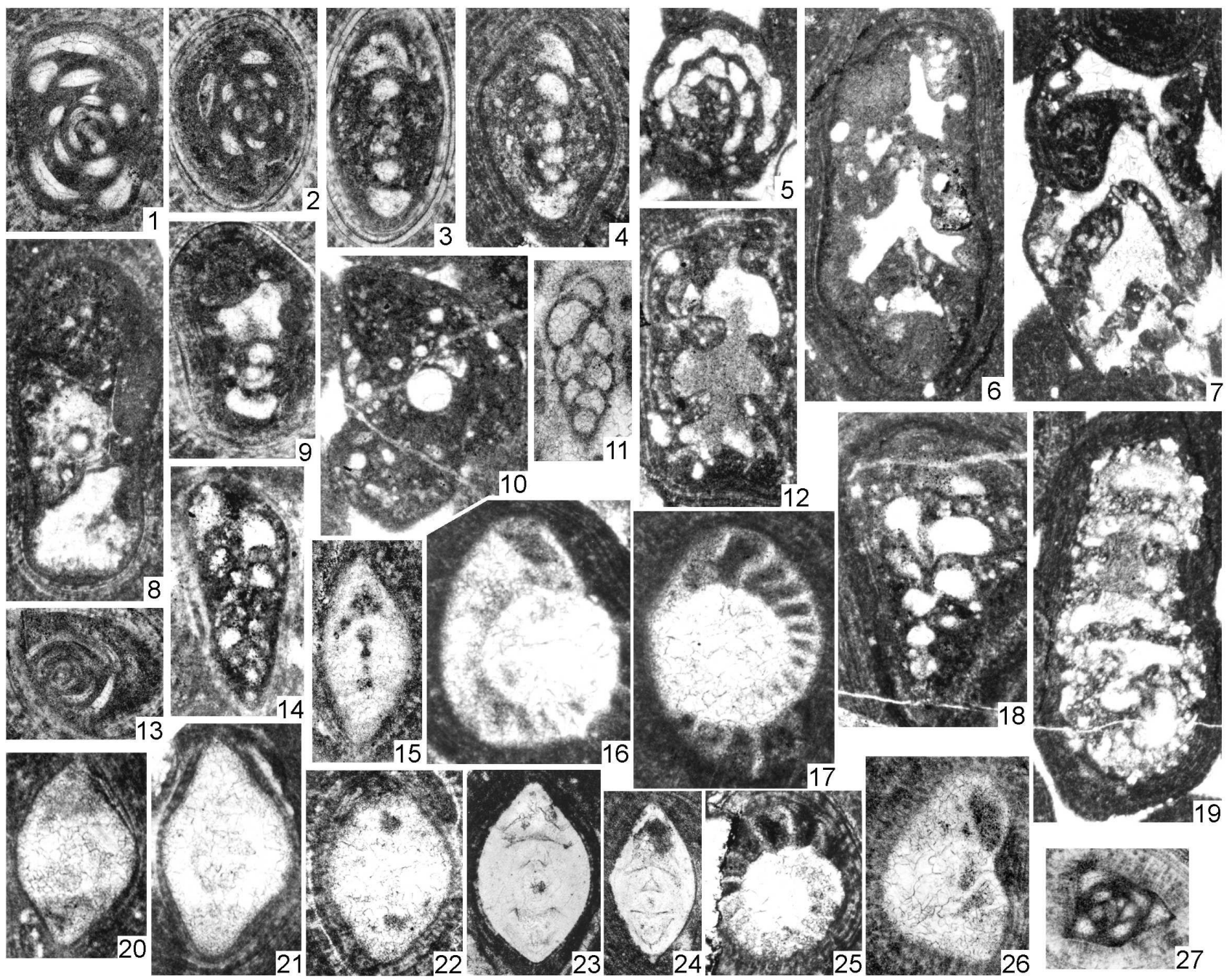

7 -

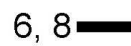

$10,12,19$

$1-5,9,11,13-18,20-26$
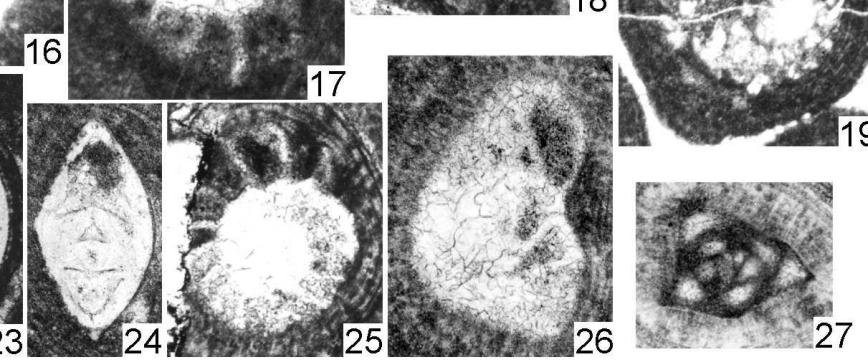

27

Scale bar $=0.2 \mathrm{~mm}$

Fig. 6. Foraminifers from Hashirimizu. 1, 2: Miliolidae indet., 1: D2-026985, 2: D2-027010; both Ha-1. 3-5: Melathrokerion spirialis Gorbachik, 3: D2-026992, 4: D2-022772, 5: D2-026992; all Ha-1. 6, 7: Haplophragmium sp. cf. H. lutzei Hanzlikova, 6: D2-022769; 7: D2-027006, both Ha-1. 8, 9: Pseudocyclammina? sp., 8: D2-022768; 9: D2-022774, both Ha-1. 10: Cyclamminidae? indet., D2-027005, Ha-1. 11: Belorussiella? sp. B, D2-027013, Ha-2. 12: Acruliammina? sp., D2026992, Ha-1. 13: Quinqueloculina sp., D2-026991, Ha-1. 14, 18: Textularia spp., 14: D2-022768, 18: D2-022766; both Ha-1. 15: Epistominid?, D2-027003, Ha-1. 16, 17, 25, 26: Chalilovella sp., 16: D2-026990, 17: D2-022766, 25: D2022764, 26: D2-027006; all Ha-1. 19: Ammobaculites sp., D2-022765, Ha-1. 20-24: Lenticulina sp., 20: D2-027003, 21: D2-022769, 22: D2-022764, 23: D2-027001, 24: D2-027006; all Ha-1. 27: Miliolidae indet., D2-026999, Ha-1.

Jura Mountains (unpublished data by R. Wernli). Pseudocyclammina is one of the commonest genus in the Upper Jurassic to Lower Cretaceous of the western Tethyan regions where the type species, $P$. lituus ranges from the Kimmeridgian to the Valanginian (e.g., Septfontaine, 1980; Thodria, 1977; Altiner, 1991; Schindler and Conrad, 1994; Bucur et al., 1995).

Based on concurrent ranges of these five and many other agglutinated species, the most probable age of the Torinosu-type limestone in the Southern Kanto Mountains was estimated as old as Tithonian to Berriasian (Kobayashi and Vuks, 2006). Similarly, the Torinosu limestone with these species is assigned to the Berriasin to Valanginian in the Sakawa area (unpublished data by authors). On the other hand, detailed age assignment of the present material is not easy even in eleven samples having these five species, since they can not be crosschecked each other because of independent occurrence in samples without any associations with other age-diagnostic species except for Sample Sk-2 (Table 1).

However, it should be noted that the materials studied entirely lack the index genera of the pre-Kimmeridian (Callovian to Kimmeridian) such as Kurnubia assignable to the Family Pfenderinidae, Alveosepta to the Hot- 


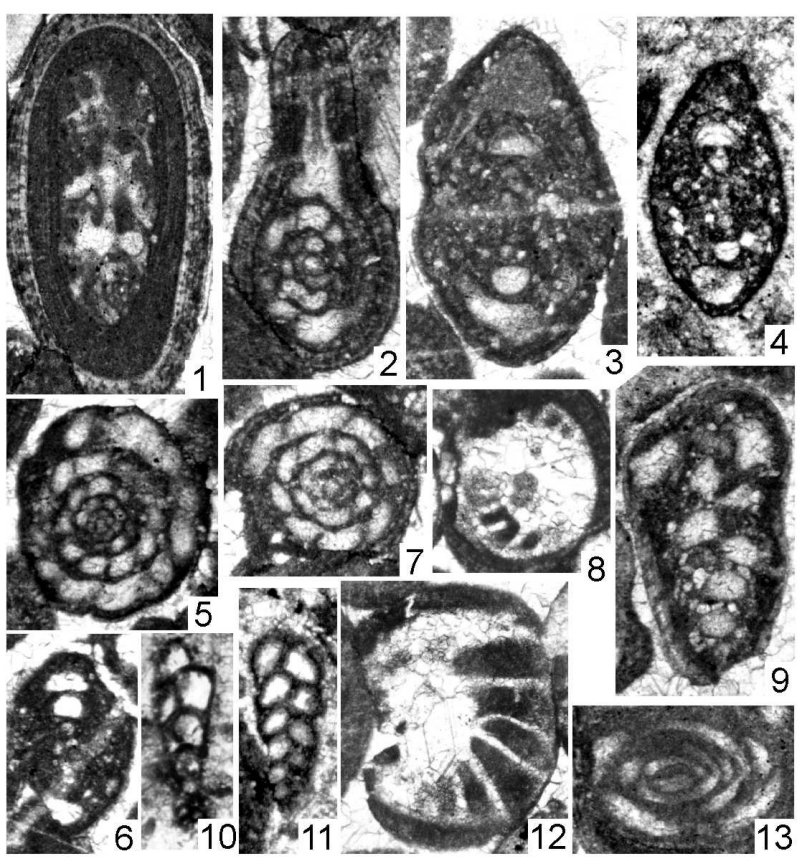

$1-9,12,13=$

10,11

Scale bar $=0.2 \mathrm{~mm}$

Fig. 7. Foraminifers from Sakamoto. 1: Haplophragmium? sp., D2-027022, Sk-1. 2: Charentia cuvillieri Neumann, D2-027029, Sk-2. 3-7: Melathrokerion spirialis Gorbachik, 3: D2-027035; 4, 6: D2-027027; 5, 7: D2-027032; all Sk-2. 8, 12: Epistominids, both D2-027029, Sk-2. 9: Valvulinidae indet., D2-027025, Sk-1. 10, 11: Belorussiella? sp., both D2-027049, Sk-5. 13: Quinqueloculina sp., D2027023, Sk-1.

tingeritidae, Parurgonina to the Chrysalidinidae, and Labyrinthina to the Orbitopsellidae (Abbate et al., 1974; Septfontaine, 1980; Clark and Boudagher-Fadel, 2002; Bucur and Săsăran, 2005), as well as those of the Torinosu and other Torinosu-type limestones in the Southern Kanto Mountains and Sakawa area. Also significant is the complete absence of the early evolutionary members of orbitolinids, the very important stratigraphic markers that are prolific in the upper Hauterivian to the lower Aptian (the Urgonian and its correlatable limestones) of Europe (Arnaud and Arnaud-Vanneau, 1991; Clavel et al., 1995, 2010; Becker, 1999; Schroeder et al., 2002). We have reconfirmed the biostratigraphic significance of these foraminifers in the southern part of the Jura Mountains. In Japan, orbitolinids first appear in late Hauterivian (Iba et al., 2011) and common in the Aptian to Albian calcareous facies (Ujiié and Kusukawa, 1968; Takashima et al., 1997; Matsumaru, 2005; Iba and Sano, 2006; Iba et al., 2011).

It appears reasonable to suppose a relatively wide chrono-stratigraphical interval for the materials containing the five species based on their stratigraphic ranges

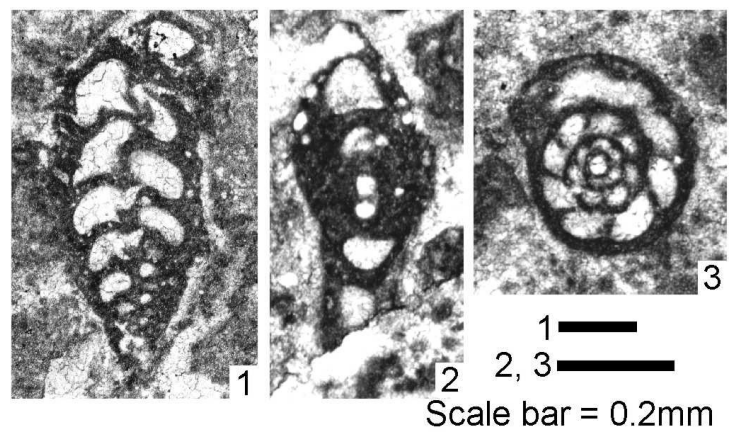

Fig. 8. Foraminifers from Shiraki. 1: Textularia sp., D2027065, Sh-1. 2, 3: Charentia cuvillieri Neumann, 2: D2027058, 3: D2-027065, Sh-1.

determined in the western Tethyan regions mentioned above. However, there are no foraminiferal faunal elements suggesting positively the pre-Kimmeridian and post-late Hauterivian ages for a calibration of the materials. These chronologic constraints on the foraminiferal materials are also applied to the Torinosu and other Torinosu-type limestones.

Accordingly, Sample Mi-1, Mi-5, and Ka-2 are thought to be dated as the Tithonian to early Hauterivian based on the occurrence of Nautiloculina broennimanni in Mi-1 and Mi-5, Freixialina planispiralis in Ka-2, and the above-mentioned chronologic constraints on them that is the absence of orbitolinids. Likewise, Ha-1 is probably assigned to the Tithonian to early Hauterivian based on the presence of Melathrokerion spirialis and the absence of orbitolinids. Sample Sk-2 with Melathrokerion spirialis and Charentia cuvillieri is dated as old as Ha-1. Five samples (Sh-1, Az-1, Az-6, Az-8, and Az10) with Charentia cuvillieri are approximately dated as old as Tithonian to early Hauterivian based on the similar interpretation as done above. The age of Nm-1 might be more restricted than that of these 10 samples and possibly assigned to Berriasian to Valanginian based on Pseudocyclammina lituus taking the Sakawa's age assignment based on its co-occurrence with Broeckinella magna as a reference.

In conclusion, these eleven samples with some of five age-diagnostic species (Nautiloculina broennimanni, Freixialina planispiralis, Charentia cuvillieri, Melathrokerion spirialis and Pseudocyclammina lituus) are better dated broadly as the latest Jurassic to earlier Early Cretaceous without further detailed assignment on account of insufficient data source of the present material in comparison with that of the Southern Kanto Mountains (Kobayashi and Vuks, 2006) and the Sakawa (unpublished data by authors). Also applied to other 20 samples lacking five age-diagnostic species are the 




Scale bar $=0.2 \mathrm{~mm}$

Fig. 9. Foraminifers from Azamui. 1-6: Charentia cuvillieri Neumann, 1: D2-050558, Az-6; 2: D2-050517, Loc. Az-6; 3: D2-050552, Az-1; 4: D2-050572, Az-8; 5: D2-050552, Az-6; 6: D2-050580, Az-10. 7: Acruliammina sp., D2-050553, Az-6. 8: Haplophragmium sp. cf. H. lutzei Hanzlikova, D2-050608, Az-14. 9, 10, 13-15: Haplophragmium sp., 9: D2-050555, Az-6; 10: D2-050550, Az-6; 13: D2-050563, Az-6; 14: D2-050569, Az-8; 15: D2-050554, Az-6. 11, 12: Belorussiella? sp., 11: D2-050558, 12: D2-050545, both Az-6. 16: Lenticulina sp., D2-050624, Az-17. 17, 19, 21: Textularia sp., 17: D2050519, Az-1; 19: D2-050558, Az-6; 21: D2-050629, Az-17. 18: Astacolus? sp. A., D2-050607, Az-14. 20: Haplophragmium? sp., D2-050627, Az-17.

chronologic constraints excluding the pre-Kimmeridgian and post-late Hauterivian faunal elements of the Torinosu-type limestones.

\section{Calibration of the Torinosu-type limestone}

Depositional period of the Torinosu-type limestone has been more precisely dated than done in 1970's based on the high resolution biostratigraphy of microfossils such as calcareous nannofossils (Aita and Okada, 1986), radiolarians (e.g., Sashida et al., 1989; N. Ishida, 2006), planktonic foraminifers (Sashida et al., 1992; Inose and Sashida, 2011), and benthic foraminifers (Kobayashi and Vuks, 2006). Most of these studies have revealed that the Torinosu-type limestone and the surrounding argillaceous rocks are roughly coeval or the former is somewhat older than the latter, and the former was emplaced tectonically into the latter. This is true of the present examples: Samples Mi-1 and Mi-5 vs. Tithonian to Berriasian Yura Formation (Yao, 1984), Ka-2 vs. Valanginian to Barremian Kamiya Formation (Yao, 1984), Sk-2 vs. Upper Jurassic Sakamoto Formation (Nishizono, 2001), Sh-1 vs. Tithonian Ebirase Unit (Nishizono et al., 1997), and Az-1, Az-6, Az-8, and Az10 vs. Lower Cretaceous (Yoshida, 1985) or Upper Jurassic (Nishi, 1994) Tsui Formation. There are no agediagnostic fossil reports from argillaceous rocks around Nm-1.

On the other hand, it should be noted that the Torinosu-type limestones in the Southern Kanto Mountains are consistently assignable to Jurassic/Cretaceous (Titho- 


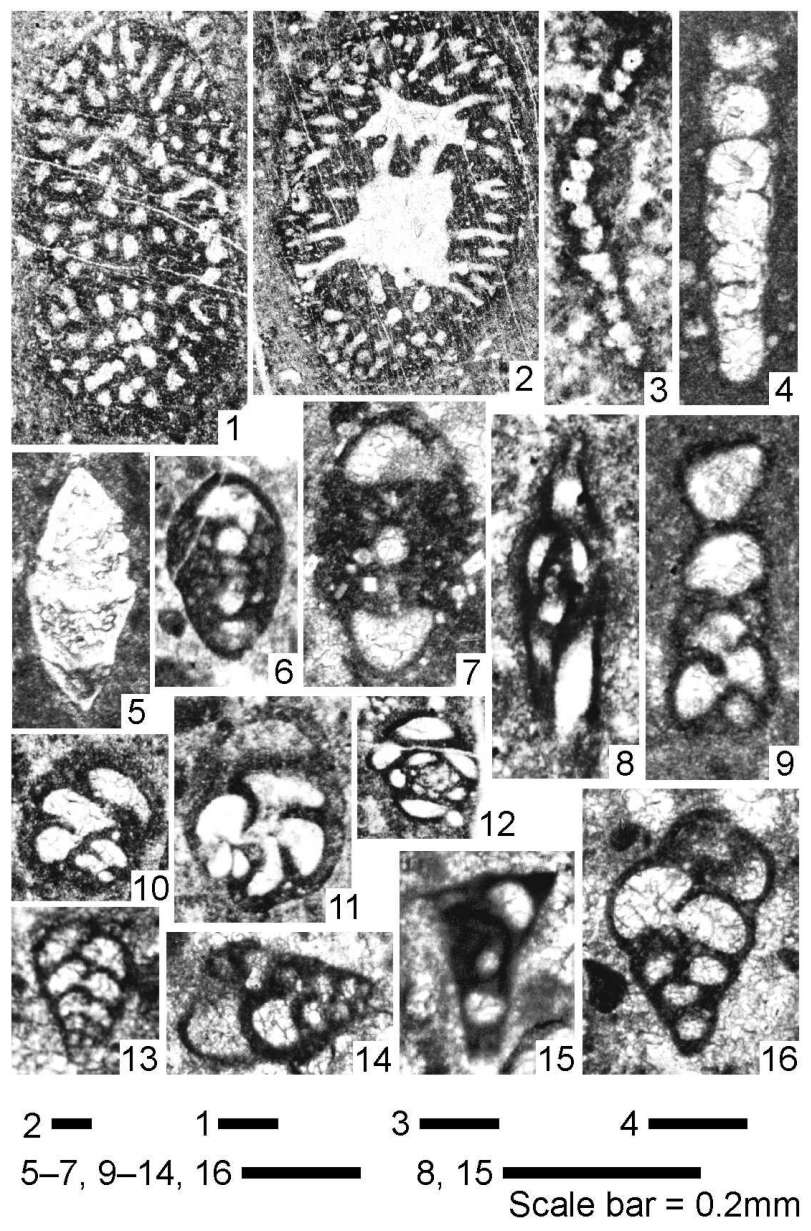

Fig. 10. Foraminifers from Nomura area. 1, 2: Pseudocyclammina lituus (Yokoyama), 1: D2-025001, Nm-1; 2: D2-025001, Nm-1. 3: Broeckinella? sp., D2-025007, Nm2. 4: Lituolinidae? indet., D2-024867, Nm-50. 5: Lenticulina sp., D2-024867, Nm-50. 6, 7: Melathrokerion sp., 6: D2-024864, Nm-50; 7: D2-025001, Nm-1. 8, 15: Miliolidae indet., 8: D2-025002, Nm-1; 15: D2-025010, Nm-2. 9: Lituolinidae sp., D2-025021, Nm-3. 10, 11: Arenobulimina sp., 10: D2-024865, 11: D2-024862; both Nm-50. 12: Quinqueloculina? sp., D2-025022, Nm-3. 13, 14, 16: Verneuilinidae indet, 13: D2-025008, 14: D2-025018, 16: D2025019; all Nm-2.

nian/Berriasian) regardless their distribution in tectonostratigraphic units from the Southern Chichibu to the Northern Shimanto Terrane (Kobayashi and Vuks, 2006). This depositional period based on the foraminiferal biostratigraphy (Kobayashi and Vuks, 2006) is largely different from Middle Jurassic (Bathonian to Callovian) age of limestones determined by radiolarians by Sashida et al. (1989) and N. Ishida (2011) from the same stratigraphic units. Moreover, still remaining uncertain in the Southern Kanto Mountains is that the limestones are apparently younger than the surrounding siliciclastic rocks in the Middle Jurassic Kamiyozawa Formation (Yasuda, 1989; Takahashi and Ishii, 1995;

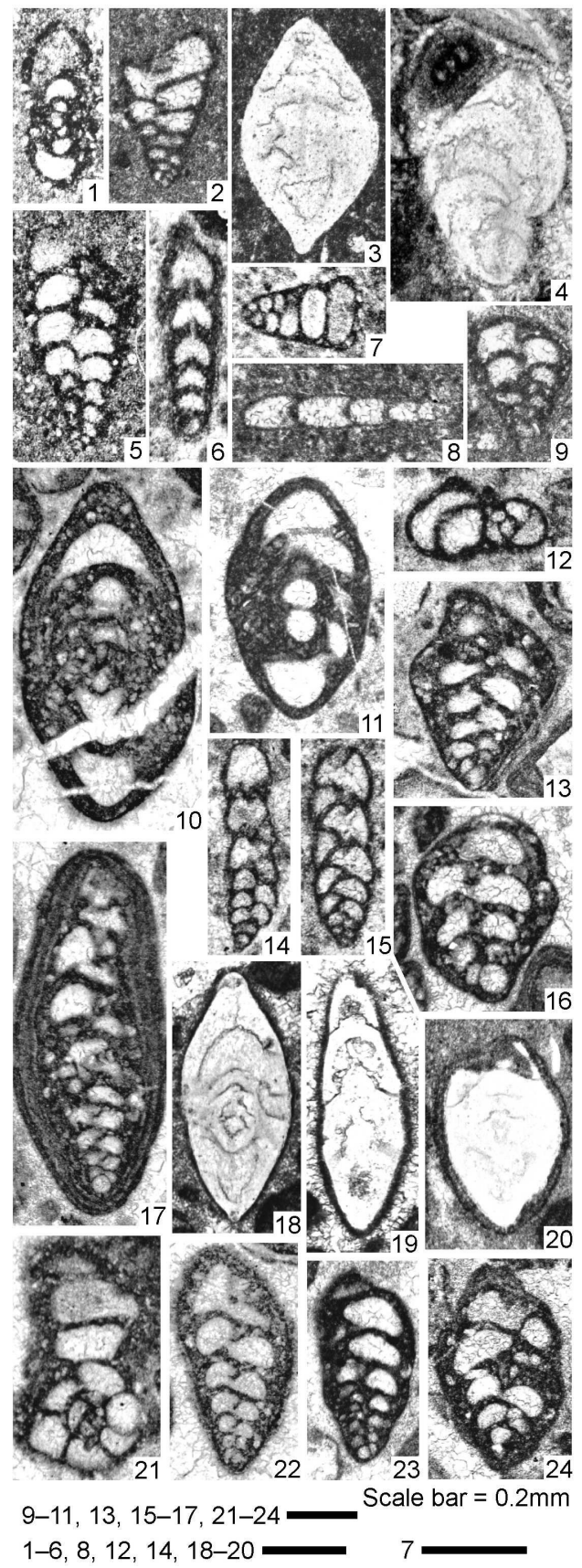

Fig. 11. Foraminifers from the Yura area. 1-9: from Kamiya and 10-24: from Mizukoshi. 1: Freixialina planispiralis Ramalho, D2-028352, Ka-2. 2, 7, 9: Verneuilinidae indet., 2: D2-028352, Ka-2; 7: D2-036798, Ka-1; 9: D2036820, Ka-4. 3: Lenticulina sp., D2-036813, Ka-3. 4: Astacolus? sp. B, D2-036798, Ka-1. 5: Textularia? sp., D2-036806, Ka-2. 6: Ammobaculites sp., D2-036798, Ka1. 8: Dentalina? sp., D2-036814, Ka-3. 10, 11: Nautiloculina broennimanni Arnaud- Vanneau and Peybernes, 10: D2-036827, Mi-1; 11: D2-036866, Mi-5. 12: Charentiidae indet., D2-036840, Mi-3. 13, 16: Valvulinidae indet., 13: D2-036877, 16: D2-036868; both Mi-5. 14, 15: Belorussiella cf. textilarioides (Reuss), 14: D2-036831; 15: D2036829, both Mi-1. 17: Textulariidae indet., D2-036877, Mi-5. 18-20: Lenticulina spp., 18, 19: both D2-036873, Mi-5; 20: D2-036835, Mi-2. 21: Ammobaculites? sp., D2036898, Mi-7. 22-24: Textularia? sp., 22: D2-036889, Mi7; 23: D2-036866, Mi-5; 24: D2-036867, Mi-5. 
Kobayashi and Vuks, 2006).

Middle Jurassic and early Late Jurassic ages of the limestones determined by radiolarians are reported from the Ebirase Formation of west Kyushu (N. Ishida, 2006) and the Northern Shimanto Terrane in eastern Shikoku (K. Ishida, 1994), respectively. The former limestone from the Ebirase Formation is comparable to the limestone exposed at Shiraki in this paper. These Middle and early Late Jurassic ages of the Torinosu-type limestones assigned by Sashida et al. (1989), K. Ishida (1994), and N. Ishida $(2006,2011)$ should be re-inspected using other methods, such as the strontium isotope stratigraphy of the limestones (Shiraishi et al., 2005; Kakizaki et al. 2012), because no pre-Kimmeridgian foraminiferal elements are recognized in them as mentioned above.

Similarly that should be reconsidered is the age assignment of the Torinosu-type limestone blocks contained in the Ishido Formation in the Sanchu area of the Kanto Mountains. Their Early Aptian age determined by planktonic foraminifers (Sashida et al., 1992; Inose and Sashida, 2011) is younger than the siliciclastic matrix age of late Hauterivian to Barremian of the formation (e.g., Matsukawa, 1988). Matsumaru et al. (2005) reported Palorbitolina lenticularis (Blumenbach, 1805) from the calcareous sandstone of the Ishido Formation and P. lenticularis, Iraqia simplex Henson, 1948, and others from the limestone of the formation and assigned both of them into the early Aptian. Orbitolinids characteristic in the Japanese Lower Cretaceous range from late Hauterivian to the later part of early Albian according to Iba et al. (2011). If the orbitolinid-bearing limestone of Matsumaru et al. (2005) is undoubtedly referable to the Torinosu-type, its assignment to the early Aptian must be reconsidered, as negatively commented on by Iba et al. (2011). Iba et al. (2011) pointed out the needs of reexamination on identification of some poorly preserved planktonic foraminifers in Sashida et al. (1992) and of Iraqia simplex appeared in Matsumaru et al. (2005) without description and illustration. They assigned calcareous sandstone with orbitolinid into late Hauterivian and both limestones studied by Sashida et al. (1992) and Matsumaru et al. (2005) into Barremian.

Black limestone blocks contained in the Shiriya Group in Aomori Prefecture (Tsushima and Takizawa, 1977) were referred to the Torinosu-type and to late Jurassic age based on occurrences of hexacorals (Onuki, 1959) and stromatoporoids (Murata, 1962). However, at least some of them, presumably referred to the Torinosu-type previously, contain megalodontoid bivalves (Sano et al., 2009) and late Triassic (Carnian) foraminifer Aulotortus sinuosus Weynschenk, 1956 (unpublished data by F. Kobayashi), which characterizes huge limestone blocks of the Southern Chichibu Terrane. On the contrary, there is an example that limestones should be reassigned to the Torinosu-type instead of the Carnian as those in the Hashirimizu area treated herein. Fossiliferous limestones exposed in the Murotsu area, Yamaguchi Prefecture (Yoshidomi and Inoue, 2001; Shiraishi and Yoshidomi, 2005) are thought to probably belong to the Torinosu-type. On account of their location in the Inner Zone of SW Japan, they have special tectonic and paleogeographic implications, though detailed age assignment to them has remained uncertain.

Studies on pre-Barremian Mesozoic foraminifers are still few in Japan. Foraminiferal faunal analysis can be applied to limestones and calcareous clastic rocks whose age is indeterminable to be either pre-Kimmeridgian or older, or post-late Hauterivian or younger. Because key taxa and faunal composition of foraminifers contained in the Torinosu-type limestone are different from those of both younger and older ones.

\section{Acknowledgments}

We are indebted to two reviewers, Shin-ichi Sano (Fukui Prefectural Dinosaurus Museum) and Rossana Martini (University of Geneva) for their critical reading of the manuscript and A. Ujimaru (Museum of Nature and Human Activities, Hyogo) for her help drawing figures. The manuscript is much improved by careful and helpful comments and suggestions by Shin-ichi Sano. Hiroyoshi Sano (Kyushu University) provided regional geology information of west Kyushu in detail and guided the sampling in the Hashirimizu and Shiraki, South of Yatsushiro area. This study was financially supported by Grant-in Aid for Scientific Research (C) of the Japanese Ministry of Education, Science and Culture in 1994 (Project No. 05640521) and in 1998 and 1999 (Project No. 10640453).

\section{References}

Abbate, E., Ficcarelli, G., Radrizzani, C. P., Salvietti, A., Torre, D. and Turi, A., 1974, Jurassic sequences from the Somali Coast to the Gulf of Aden. Riv. Ital. Paleont., 80, 409-478.

Aita, Y. and Okada, H., 1986, Radiolarians and calcareous nannofossils from the uppermost Jurassic and Lower Cretaceous strata of Japan and Tethyan regions. Micropaleont., 32, 97-128.

Altiner, D., 1991, Microfossil biostratigraphy (mainly foraminifers) of the Jurassic-Lower Cretaceous carbonate successions in north-western Anatolia, Turkey. Estratto Geol. Romana, 27, 167-213.

Arnaud, H. and Arnaud-Vanneau, A., 1991, Les Calcaires urgoniens des Massifs subalpins septentrionaux et du Jura (France): Age et discussion des données stratigraphiques, Géol. Alpine, 67, 63-79. (in French with English abstract)

Arnaud-Vanneau, A. and Peybernes, B., 1978 Les représentants 
Eocrétacés du genre Nautiloculina Mohler, 1938 (foraminifera, Fam. Lituolidae?) dans les chaînes subalpines septentrionales (vercors) et les Pyrénées franco-espagnoles. Geobios, 11, 67-81. (in French with English abstract)

Becker, E., 1999, Orbitoliniden-Biostratigraphie der Unterkreide (Hauterive-Barrême) in den spanischen Pyrenäen (Profil Organyà, Prov. Lérida). Rev. Paléobiol., 18, 359-489. (in German with English abstract).

Blumenbach, J. F., 1805, Abbildungen naturhistorischer Gegenstände, Heft 8 (80), H. Dieterich, Göttingen, 2p. (in German)

Bucur, I. I., Cociuba, I. and Cociuba, M., 1993, Microfacies and microfossils in the Upper Jurassic-Lower Cretaceous limestone in the southern part of the Pădurea Craiului Mountains. Romanie Jour. Strat., 75, 33-40.

Bucur, I. I., Conrad, M. A. and Radoicic, R., 1995, Foraminifers and calcareous algae from Valanginian limestones in the Jerma river canyon, eastern Serbia. Rev. Paléobiol., 14, 349-377.

Bucur, I. I., Koch, R., Kirmaci, Z. and Tasli, K., 2004, Foraminifères du Jurassique supérieur et du Crétacé inférieur (Calcaire de Berdiga) de Kircaova (région de Kale-Gümüshane, NE Turquie). Rev. Paléobiol., 23, 209-225. (in French with English abstract)

Bucur, I. I. and Săsăran, E., 2005, Micropaleontological assemblages from the Upper Jurassic-Lower Cretaceous deposits of Trascău Mountains and their biostratigraphic significance. Acta Palaeont. Roman., 5, 27-38.

Chablaris, J., Martini, R., Kobayashi, F., Stamfli, G. and Onoue, T., 2011, Upper Triassic foraminifers from Panthalassan carbonate buildips of southwestern Japan and their paleobiogeographic implications. Micropaleont., 57, 93-124.

Cherchi, A. and Schroeder, R., 2005, Torinosuella peneropliformis (Yabe \& Hanzawa, 1926) (Lituolacea, Foraminiferida) from the Early Cretaceous of the Pedraforca massif (Catalonian Pyrenees, NE Spain). Treb. Mus. Geol. Barcelona, 13, 5-13.

Clark, G. N. and Boudagher-Fadel, M. K., 2002, Larger foraminiferal assemblages and stratigraphy of the late Jurassic Bhanness complex, Central Lebanon. Rev. Paléobiol., 21, 679-695.

Clavel, B., Busnardo, R., Charollais, J., Conrad, M. and Granier, 2010, Répartition biostratigraphique des orbitolinidés dans la biozonation à ammonites (plate-forme urgonienne du Sud-Est de la France) Partie 1: Hauterivien superior Barrémien basal. Carnets de Géol., Art. 2010/06, 1-30. (in French with English abstract)

Clavel, B., Charollais, J., Schroeder, R. and Busnardo, R., 1995, Réflexions sur la biostratigraphie du Crétacé inférieur et sur sa complémentarité avec l'analyse séquentielle: exemple de l'Urgonien jurassien et subalpine. Bull. Soc. Geol. France, 166, 663-680. (in French with English abstract)

Dulub, V. G., 1972, Foraminifers of the Upper Jurassic-Lower Cretaceous deposits of the Volyno-Podol borders of the Russian platform and Precarpathians flexure. Nedra, Tudy UkrNIGRI, 27, 5-54. (in Russian)

Dulub, V. G. and Zhabina, N. N., 1993, Distribution and conditions of existence of foraminifers from Tithonian and Berriasian of southeastern Crimea. Geol. Zhur., 1, 102-113. (in Russian)

Eguchi, M., 1951, Mesozoic hexacorals from Japan. Sci. Rep. Tohoku Univ., 2nd Ser. (Geol.), 24, 1-96.

Gorbachik, T. N., 1968, Phenomenon of the homeomorphy of foraminifers. Paleontol. Zhur., 1, 3-10. (in Russian)

Henson, F. R. S., 1948, Larger imperforate Foraminifera of southwestern Asia, Families Lituolidae, Orbitolidae and Meandrospinidae. British Museum (Nat. History), 127 p.

Huzimoto, H., 1939, On the Torinosu Series of the Kwanto
Mountainland. Jubilee Publication in the Commemoration of Prof. H. Yabe's 60th Birthday, Kokusai-Bunken, Tokyo, 457-479.*

Iba, Y. and Sano, S., 2006, Mesorbitolina (Cretaceous larger foraminifera) from the Yezo Group in Hokkaido, Japan and its stratigraphic and paleobiogeographic significance. Proc. Japan Acad., Ser. B, 82, 216-223.

Iba, Y., Sano, S. and Miura, T., 2011, Orbitolinid foraminifers in the Northwest Pacific: Their taxonomy and stratigraphy. Micropaleont., 57, 163-171.

Inose, H. and Sashida, K., 2011, Lithofacies, biota and geological age of limestone blocks in the Ishido Formation of the Cretaceous Sanchu Group, central Japan. Kaseki (Fossils), no. $89,5-14$.* $^{*}$

Ishida, K., 1994, Radiolarian age of the Torinosu-type limestone in the north of Shimanto Terrane, east Shikoku. Jour. Geol. Soc. Japan, 100, 312-315.**

Ishida, N., 2006, Sedimentary evolution of the Torinosu-type limestone bearing strata in the Southern Chichibu Terrane: A case study of the Upper Jurassic Ebirase Formation in the middle stream of the Kuma Rover, Kumamoto Prefecture. Kumamoto Jour. Sci. (Earth Sci.), 18, 69-87. *

Ishida, N., 2011, An exotic body of the Middle Jurassic Torinosu-type limestone in the Hikawa Formation, Southern Kanto Mountains, Japan. Mem. Fukui Pref. Dinosaurus Mus., 10, $103-112$.

Kakizaki, Y., Ishikawa, T., Nagaishi, K., Tanimizu, M., Hasegawa, T. and Kano, A., 2012, Strontium isotope ages of the Torinosu-type limestones (latest Jurassic to earliest Cretaceous, Japan): Implication for biocalcification event in northwestern Palaeo-Pacific. Jour. Asian Earth Sci., 46, 140-149.

Kambe, N. and Teraoka, Y., 1968, Geology of the Usuki District. With Geological Sheet Map at 1:50,000. Geol. Surv. Japan, 77 p. *

Kanmera, K. and Furukawa, H., 1964, Stratigraphy of the Upper Permian and Triassic Konose Group of the Sambosan Belt in Kyushu. Sci. Rep., Fac. Sci., Kyushu Univ., Geol., 6, 237-258.*

Kashiwagi, K. and Yao, A., 1999, Upper Jurassic to Lower Cretaceous Ikenoue Formation around Kurosegawa Terrane in the western Kii Peninsula, Southwest Japan. Jour. Geol. Soc. Japan, 105, 523-534.*

Kimura, T., 1956, The Torinosu Group and the Torinosu Limestone in the Togano and Go basins, Kochi Prefecture. Jour. Geol. Soc. Japan, 62, 515-526.*

Kobayashi, F. and Vuks, V. Ja., 2006, Tithonian-Berriasian foraminiferal faunas from the Torinosu-type calcareous blocks of the southern Kanto Mountains, Japan: their implications for post-accretionary tectonics of Jurassic to Cretaceous terranes. Geobios, 39, 833-843.

Kozai, T., Ishida, K. and Kondo, Y., 2004, Radiolarian ages and bivalve fauna of the Birafu Formation, central Shikoku. News, Osaka Micropaleontologists, spec. vol., no. 13, 149165.*

Kuznetzova, K. I. and Gorbachik, T. N., 1985, Upper Jurassic and Lower Cretaceous stratigraphy and foraminifers of the Crimea. Russian Acad. Nauk, Geol. Inst., 136 p. (in Russian)

Matsukawa, M., 1988, Barremian ammonites from the Ishido Formation, Japan: Supplements and faunal analysis. Trans. Proc. Palaeont. Soc. Japan, N.S., no. 149, 369-416.

Matsumaru, K., 2005, Praeorbitolinoides, a new orbitolinid foraminiferal genus from the lower Aptian (Cretaceous) of Hokkaido, Japan. Micropaleont., 51, 93-99.

Matsumaru, K., Yoshida, A. and Hayashi, A., 2005, Orbitolinid foraminifera from the lower Aptian Ishido Formation of the Sanchu Cretaceous System, Kanto Mountains, central Ja- 
pan. Jour. Palaeont. Soc. India, 50, 55-60.

Matsumoto, T. and Kanmera, K., 1964, Geology of the Hinagu District. With Geological Sheet Map at 1:50,000. Geol. Surv. Japan, 147 p.*

Maync, W., 1959, Biocaractères et analyse morphométrique des espèces jurassiques du genre Pseudocyclammina (Foraminifères), I. Pseudocyclammina lituus (Yokoyama). Rev. Micropaléont., 2, 153-172. (in French with English abstract)

Mori, K., 1963, Geology and paleontology of the Jurassic Somanakamura Group, Fukushima Prefecture, Japan. Sci. Rep., Tohoku Univ. 2nd Ser. (Geol.), 35, 33-65.

Morino, Y., 1993, Depositional environments of the Lower Cretaceous Torinosu type limestone in the Monobe area, Kochi Prefecture. Jour. Geol. Soc. Japan, 99, 173-183.*

Murata, M., 1962, The Upper Jurassic of Cape Shiriya, Aomori Prefecture, Sci. Rep., Tohoku Univ. 2nd Ser. (Geol.), spec. vol., no. 5, 119-126.

Nakagawa, C., Suyari, K., Ichikawa, K., Ishii, K. and Yamashita, N., 1959, Geology of Kurosegawa district, Ehime Prefecture (Studies on the Chichibu-Terrain in Shikoku, IV). Bull. Gakugei, Tokushima Univ., Nat. Sci., 9, 33-58. *

Neumann, M., 1965, Contribution a l' étude de quelques lituolidés du Cénomanien de l' İle Madame (Charente-Maritime). Rev. Micropaléont., 8, 90-95. (in French with English abstract)

Nishi, T., 1994, Geology and tectonics of the Sambosan Terrane in eastern Kyushu, Southwest Japan: Stratigraphy, sedimentological features and depositional setting of the Shakumasan Group. Jour. Geol. Soc. Japan, 100, 199-215.

Nishizono, Y., 2001, Jurassic radiolarians from the Sakamoto Formation in the Kurosegawa Terrane, Kyushu, Southwest Japan. News, Osaka Micropaleontologists, spec. vol., no. 12, 203-214.*

Nishizono, Y., Sato, T. and Murata, M., 1997, A revised Jurassic radiolarian zonation for the Southern Belt of the Chichibu terrane, western Kyushu, Southwest Japan. Marine Micropaleont., 30, 117-138.

Onuki, Y., 1959, Discovery of hexacoral from Shiriya, Aomori Prefecture (Short Report). Jour. Geol. Soc. Japan, 65, $248 . * *$

Onuki, Y., 1981, Geology of the Kitakami River Basin. Explanatory text on the Geological Map of the Kitakami River Basin, Japan (Scale 1: 200,000). Hase Geol. Surv. Office, Sendai, 307 p.**

Ramalho, M. M., 1969, Quelques observations sur les Lituolidae (foraminifera) du Malm Portugaris. Bol. Soc. Géol. Portugal, 17, 37-50. (in French with English abstract)

Salvini-Bonnard, G., Zaninetti, L. and Charollais, J., 1984, Les foraminiferes dans le Cretace Inferieur (Berriasien MoyenValanginien Inferieur) de la region de la corraterie, GrandSaleve (Haute-Salvoice, France): Inventaire preliminaire et remaques stratigraphiques. Rev. Paléobiol., 3, 175-184. (in French with English abstract)

Sano, S., Sugisawa, N. and Shimaguchi, T., 2009, Discovery of megalodontoid bivalves in the Shiriya area, northern Hons$\mathrm{hu}$, Northeat Japan, and its geological implications. Mem. Fukui Pref. Dinosaurus Mus., 8, 51-57.

Sashida, K., Igo, H., Adachi, S. and Ito, S., 1989, Radiolarian dating of the Torinosu-type limestone in the Kanto Mountains, central Japan. Ann. Rep., Inst. Geosci., Univ. Tsukuba, $15,54-60$.

Sashida, K., Igo, H., Adachi, S. and Ito, S., 1992, Foraminifers from the "Torinosu Limestone" embedded in the Ishido Formation of the Sanchu Cretaceous System, Kanto Mountains, central Japan. In Ishizaki, K. and Saito, T., eds., Centenary of Japanese Micropaleontology, Terra Scientific Pub. Co., Tokyo, 273-280.
Schindler, U. and Conrad, M. A., 1994, The Lower Cretacous dasycladales from northwestern Friuli platform and their distribution in chrolostratigraphic and cyclostratigraphic units. Rev. Paléobiol., 13, 59-96.

Schroeder, R., Clavel, B., Cherchi, A., Busnardo, R., Charollais, J. and Decrouez, D., 2002, Lignées phylétiques d' Orbitolinidés de 1' intervalle Hauterivien supérieur-Aptien inférieur; leur importance stratigraphique. Rev. Paléobiol., 21, 853-863. (in French with English abstract)

Septfontaine, M., 1978, Broeckinella magna n. sp., un nouveau grand Foraminifère dans le Valanginien du Jura Méridional (Savoie, France). Rev. Micropaléont., 21, 28-38. (in French with English abstract)

Septfontaine, M., 1980, Les foraminifères imperforés des milieux de plateforme au Mésozoïque: determination pratique, interpretation phylogénétique et utilization biostratigraphique. Rev. Micropaléont., 23, 169-203. (in French with English abstract)

Shiraishi, F., Hayasaka, Y., Takahashi, Y., Tanimizu, M., Ishikawa, T., Matsuoka, J., Murayama, M. and Kano, A., 2005, Strontium isotope age of the Torinosu Limestone in Niyodo Village, Kochi Prefecture, SW Japan. Jour. Geol. Soc. Japan, 111, 610-623.*

Shiraishi, F. and Yoshidomi, K., 2005, Depositional environment of the upper Jurassic-lower Cretaceous reef limestone in western Yamaguchi Prefecture, Southwest Japan. Jour. Geol. Soc. Japan, 111, 21-28.*

Takahashi, O. and Ishii, A., 1995, Radiolarian assemblagezones in the Jurassic and Cretaceous sequence in the Kanto Mountains, central Japan. Mem. Fac. Sci., Kyushu Univ., ser. $D, 24,49-85$.

Takashima, R., Nishi, H., Saito, T. and Hasegawa, T., 1997, Geology and planktonic foraminiferal biostratigraphy of Cretaceous strata distributed along the Shuparo River, Hokkaido, Japan. Jour. Geol. Soc. Japan, 103, 543-563.*

Takei, M. and Matsuoka, A., 2004, Megafossil-bearing mudstone blocks in the Oriai Formation of the Upper Jurassic Imaidani Group in the Shirokawa area, Ehime Prefecture, Southwest Japan. Jour. Geol. Soc. Japan, 110, 146-157.*

Tamura, M., 1959a, Taxodonta and Isodonta from the Upper Jurassic Sakamoto Formation in central Kyushu, Japan. Trans. Proc. Palaeont. Soc. Japan, N. S., no. 34, 53-65.

Tamura, M., 1959b, Some pelecypods from the Upper Jurassic Sakamoto Formation in central Kyushu, Japan. Trans. Proc. Palaeont. Soc. Japan, N. S., no. 35, 113-120.

Tamura, M., 1960, Stratigraphical study on the Sakamoto Group in Kyushu. Jour. Geol. Soc. Japan, 66, 371-370. *

Tamura, M., 1961a, The Torinosu Series and fossils therein. Japan. Jour. Geol. Geogr., 32, 219-251.

Tamura, M., 1961b, The geologic history of the Torinosu Epoch and Mesozoic reef-limestone in Japan. Japan. Jour. Geol. Geogr., 32, 253-277.

Tamura, M., 1983, Megalodonts and megalodont limestone in Japan. Mem. Fac. Educ., Kumamoto Univ., Nat. Sci., 32, $7-28$.

Thodria, V. A., 1977, Late Jurassic foraminifers of Racha and southern Osetia. Paleontology and Sratigraphy of the Mesozoic Deposits of Georgia, Metsniereba, Tbilisi, 43-61. (in Russian)

Tsushima, K. and Takizawa, F., 1977, Geology of the Shiriyazaki District. With Geological Sheet Map at 1:50,000. Geol. Surv. Japan, 36 p. *

Ujiié, H. and Kusukawa, T., 1968, Orbitolina (Cretaceous Foraminifera) from the Miyako Group, Iwate Prefecture, Northeast Japan. Mem. Nat. Sci. Mus., Tokyo, no. 1, 29-32.*

Weynschenk, R., 1956, Aulotortus, a new genus of Foraminifera from the Jurassic of Tyrol, Austria. Contr. Cushman Found. Foram. Res., 7, 26-28. 
Yabe, H. and Hanzawa, S., 1926, Choffatella Schlunberg and Pseudocyclammina, a new genus of arenaceous foraminifera. Sci. Rep. Tohoku Univ., 2nd Ser. (Geol.), 9, 9-11.

Yabe, H. and Sugiyama, T., 1935, Jurassic stromatoporoids from Japan. Sci. Rep., Tohoku Univ., 2nd Ser. (Geol.), 24, $1-96$.

Yamagiwa, N., Ishihara, S. and Ito, A., 2011, A new species of Amphiastraea (Scleractinia) from the Torinosu Group, Kochi Prefecture, Southwest Japan. Mem. Osaka Kyoiku Univ., Ser. 3, 60, 17-25.

Yao, A., 1984, Subdivision of the Mesozoic complex in KiiYura area, Southwest Japan and its bearing on the Mesozoic basin development in the Southern Chichibu Terrane. Jour. Geosci., Osaka City Univ., 27, 41-103.

Yao, A., Matsuoka, A. and Nakatani, T., 1982, Triassic and Jurassic radiolarian assemblages in Southwest Japan. News, Osaka Micropaleontologists, Spec. vol., no. 5, 27-43. *

Yasuda, M., 1989, Equivalents to the Torinosu Group of the Chichibu Belt in the southeastern part of the Kanto Mountains, central Japan: Lithology and radiolarian biostratigraphy. Jour. Geol. Soc. Japan, 95, 463-478.*

Yokoyama, M., 1890, Foraminiferen aus dem Kalksteine von Torinosu und Kompira. Denksch. Kaiser. Akad., Wiss. Mat.Natur. Kl., 57, 26-27.

Yoshida, E., 1985, Geology of the northeastern part of Saeki City, Oita Prefecture, and reexamination of the Butsuzo Tectonic Line. Jour. Geol. Soc. Japan, 91, 867-877. *

Yoshidomi, K. and Inoue, Y., 2001, Late Mesozoic coral-bearing limestone in the Murotsu area, Toyoura Town, western Yamaguchi Prefecture, Southwest Japan. Jour. Geol. Soc. Japan, 107, 794-797.*

* in Japanese with English abstract

$* *$ in Japanese

\begin{tabular}{|c|c|}
\hline Azamui & 浅海井 \\
\hline Ebirase Unit & 箙瀬ユニット \\
\hline Hashirimizu & 走水 \\
\hline Imaidani Group & 今井谷層群 \\
\hline Ishido Formation & 石堂層 \\
\hline Iwaizumi & 岩泉 \\
\hline Kamiya & 神谷 \\
\hline Kamiyozawa Formation & 上養沢層 \\
\hline Konose Group & 神瀬層群 \\
\hline Matsukuma Formation & 松求麻層 \\
\hline Mizukoshi Pass & 水越峠 \\
\hline Murotsu & 室津 \\
\hline Nakano Belt & 中野帯 \\
\hline Nomura & 野村 \\
\hline Sakamoto & 坂本 \\
\hline Sakawa & 佐川 \\
\hline Sakuraga Pass & 桜が峠 \\
\hline Sanchu & 山中 \\
\hline Shiraki & 白木 \\
\hline Shiriya Group & 尻屋層群 \\
\hline Shirokawa & 城川 \\
\hline Soma & 相馬 \\
\hline Torinosu & 鳥巣 \\
\hline Tsui Formation & 津井層 \\
\hline Yatsushiro & 八代 \\
\hline Yukagi Formation & 床木層 \\
\hline Yura & 由良 \\
\hline
\end{tabular}

(要 旨)

Kobayashi, F. and Wernli, R., 2013, Latest Jurassic to earlier Early Cretaceous foraminifers from the Torinosu-type limestone blocks in Southwest Japan: Constraints on chrolonogic calibration of the Torinosu-type limestones. Jour. Geol. Soc. Japan, 119, 25-38. （小林文夫・Roland Wernli, 2013, 西南日本の鳥巣型石灰岩ブロッ クのジュラ紀最後期から白亜紀古世前期有孔虫化石：鳥巣型石灰岩年代決定に関わる制約 要素. 地質䧱, 119, 25-38.)

西南日本の八代南方・浅海井・野村・由良地域の鳥巣型石灰岩 31 試料から 36 分類群の 有孔虫化石が識別された. 種レベルで同定されたものはNautiloculina broennimanni, Freixialina planispiralis, Charentia cuvillieri, Melathrokerion spirialis, Pseudocyclammina lituus の 5 種に限られる. 先 Kimmeridian 期を指示する Kurnubia 属や Alveosepta 属など, また, 後 Hauterivian 晚期を示唆する orbitolinid の仲間は本試料からはまっ たく見出されなかった. 同定された 5 種のテーチス海西域における生層序学的分布や，先 Kimmeridian 期ならびに後 Hauterivian 晚期要素が除外されるという制約から本研究で取 り扱つた鳥巣型石灰岩の年代はジュラ紀最後期から白亜紀古世前期とされる. 